\title{
The Formation of Halogen-Specific TOX from Chlorination and
} Chloramination of Natural Organic Matter Isolates

3

4 Ina Kristiana $^{1,2,3}$, Hervé Gallard ${ }^{1}$, Cynthia Joll ${ }^{2,3}$ and Jean-Philippe Croué ${ }^{1}$ 5

$6 \quad{ }^{1}$ Laboratoire de Chimie et Microbiologie de l'Eau UMR CNRS 6008

7 Université de Poitiers, 40 Avenue du Recteur Pineau, 86000 Poitiers, France

8

$9 \quad{ }^{2}$ Curtin Water Quality Research Centre

10 Curtin University of Technology, Kent Street, Bentley 6102, Perth, Australia

11

$12{ }^{3}$ Cooperative Research Centre for Water Quality and Treatment, Australia

13

14

15 Corresponding author:

16 Ina Kristiana

17 Present postal address : Curtin Water Quality Research Centre

18 Department of Applied Chemistry, Curtin University of Technology

19 GPO Box U1987 Perth WA 6845 Australia

$20 \mathrm{Ph}$

: 610892667442

$21 \quad$ Fax

: 610892662300

22 E-mail

: I.Kristiana@curtin.edu.au 


\section{$1 \quad$ Abstract}

2 The formation of disinfection by-products (DBPs) is a public health concern. An important way

3 to evaluate the presence of DBPs is in terms of the total organic halogen (TOX), which can be

4 further specified into total organic chlorine (TOCl), bromine (TOBr), and iodine (TOI). The

5 formation and distribution of halogen-specific TOX during chlorination and chloramination of

6 natural organic matter (NOM) isolates in the presence of bromide and iodide ions were studied.

7 As expected, chloramination produced significantly less TOX than chlorination. TOCl was the

8 dominant species formed in both chlorination and chloramination. TOI was always produced in

9 chloramination, but not in chlorination when high chlorine dose was used, due to the limited

10 presence of $\mathrm{HOI}$ in chlorination as a result of the oxidation of iodide to iodate in the presence of

11 excess chlorine. The formation of TOI during chloramination increased as the initial iodide ion

12 concentration increased, with a maximum of $\sim 60 \%$ of the initial iodide ion becoming

13 incorporated into NOM. Iodine incorporation in NOM was consistently higher than bromine

14 incorporation, demonstrating that the competitive reactions between bromine and iodine species

15 in chloramination favoured the formation of $\mathrm{HOI}$ and thus TOI, rather than TOBr. Correlations

16 between the aromatic character of the NOM isolates $\left(\mathrm{SUVA}_{254}\right.$ and \% aromatic C) and the

17 concentrations of overall TOX and halogen-specific TOX in chloramination were observed. This

18 indicates that the aromatic moieties in NOM, as indicated by $\mathrm{SUVA}_{254}$ and $\%$ aromatic C, play an

19 important role in the formation of overall TOX and halogen-specific TOX in chloramination.

20 THMs comprised only a fraction of TOX, up to $7 \%$ in chloramination and up to $47 \%$ in

21 chlorination. Although chloramine produces less TOX than chlorine, it formed proportionally

22 more non-THM DBPs than chlorine. These non-THM DBPs are mostly unknown, corresponding

23 to unknown health risks. Considering the higher potential for formation of iodinated DBPs and 
1 unknown DBPs associated with the use of chloramine, water utilities need to carefully balance

2 the risks and benefits of using chloramine as an alternative disinfectant to chlorine in order to 3 satisfy guideline values for THMs.

6 Keywords: Total organic halogen, iodide, bromide, disinfection by-products, trihalomethanes, 7 chlorination, chloramination, natural organic matter

\section{Introduction}

11 Disinfection is an integral part of drinking water treatment due to its crucial role in preventing the

12 spread of water-borne diseases. However, as well as inactivating microorganisms in the water,

13 chemical disinfectants also react with natural organic matter (NOM) and inorganic materials in

14 the water, producing disinfection by-products (DBPs). The formation of DBPs from disinfection

15 practices is a public health concern and a drinking water treatment problem (Richardson et al., 16 2002).

17

18 Organic DBPs can be quantified as individual species, e.g. trihalomethanes (THMs), haloacetic 19 acids (HAAs), and haloacetonitriles (HANs), or as total organic halogen (TOX). TOX is a group

20 parameter that is used to characterise the incorporation of halogen into organic molecules,

21 regardless of their identity. Chlorine and chloramine are the two major disinfectants that produce 22 significant amounts of TOX. In chlorinated samples, only about $50 \%$ of TOX can reportedly be 23 assigned to individual species, while, in chloraminated samples, the corresponding value is less 
1 than 20\% (Richardson, 2003; Li et al., 2002). TOX therefore provides a measure of the overall

2 organic halogenated DBP formation which cannot be provided by analysis of specific DBPs. It is

3 also an alternative to the measurement of individual DBPs, which cannot be done routinely due to

4 the diversity and the large range of molecular weights of the DBPs formed.

6 In the presence of bromide and iodide ions, chlorinated organic compounds (TOCl), as well as

7 brominated (TOBr) and iodinated (TOI) organic compounds, are formed. TOX analysis can thus

8 be further specified into $\mathrm{TOCl}, \mathrm{TOBr}$, and TOI. The knowledge of the proportions of $\mathrm{TOBr}$ and

9 TOI is important for the evaluation of the health risks of DBPs. Brominated and iodinated DBPs

10 are now being recognised as toxicologically important. Many brominated DBPs have been shown

11 to be more carcinogenic than their chlorinated analogues, while iodinated compounds may be

12 more toxic than their brominated analogues (Plewa et al., 2004; Li et al., 2002).

13

14 The conventional method for TOX measurement combines carbon adsorption, pyrolysis, and

15 measurement of hydrogen halide by microcoulometry. The method cannot differentiate between

16 the different halides as it measures all halogens as chloride equivalents. In order to differentiate

17 the halogen constituents in TOX, a different method of halide detection is required. Ion

18 chromatography has been the popular choice for the differential analysis of TOCl, TOBr, and

19 TOI (Hua and Reckhow, 2006; Echigo et al., 2000; Oleksy-Frenzel et al., 2000). Using ion

20 chromatography, chloride, bromide, and iodide ions contained in the halide mixture can be

21 individually measured.

23 There have been many studies reporting the formation and behaviour of TOX from chlorination

24 of water samples and NOM isolates (e.g. Li et al., 2002; Baribeau et al., 2001; Pourmoghaddas 
1 and Stevens, 1995). However, there are only a few studies on the formation of TOX from

2 chloramination (Wu et al., 2003; Diehl et al., 2000; Symons et al., 1998), and those that compare

3 the formation of TOX from chlorination and chloramination of water samples and NOM isolates

4 (Hua and Reckhow, 2007; Wu et al., 2003; Zhang et al., 2000). The extent to which bromide and

5 iodide ions can influence the formation of TOX is also not well known. Most of the previously

6 published studies only measured TOX, not the halogen-specific fractions of TOX (TOCl, TOBr,

7 and TOI). Echigo et al. (2000) compared the concentrations of $\mathrm{TOCl}$ and $\mathrm{TOBr}$ in water samples

8 treated with chlorine, chloramine, and chlorine dioxide, while Oleksy-Frenzel et al. (2000)

9 measured the concentrations of $\mathrm{TOCl}, \mathrm{TOBr}$, and $\mathrm{TOI}$ in drinking water and wastewater samples.

10 Recently, the formation of all three species of TOX (TOCl, TOBr, and TOI) from chlorination of 11 natural waters in the presence of bromide and iodide ions was reported (Hua and Reckhow, 2006;

12 Hua et al., 2006).

13

14 This work aimed to bridge the knowledge gaps in studies of TOX formation. The formation and

15 distribution of halogen-specific TOX, namely TOCl, TOBr, and TOI, upon chlorination and

16 chloramination of natural organic matter (NOM) isolates in the presence of bromide and iodide

17 ions were studied. This is the first study to investigate the influence of the characteristics of

18 NOM and the concentrations of bromide and iodide ions on the formation of all three species of

19 halogen-specific TOX in chloramination.

\section{Materials and Methods}

\section{$22 \quad 2.1 \quad$ NOM Samples}


1 NOM samples were collected from the following sources: Loire River and Ribou Reservoir in

2 France; and Suwannee River, Colorado River, and South Platte River in the United States. The

3 NOM in raw water samples from these sources was fractionated using XAD resins. Details of the

4 fractionation procedure have been presented elsewhere (Croué et al., 2000). The hydrophobic

5 (HPO) fraction refers to the NOM fraction recovered from the XAD-8 resin by elution with an

6 acetonitrile/water mixture; the hydrophobic acid (HPOA) fraction refers to the NOM fraction

7 recovered from the XAD-8 resin by elution with $\mathrm{NaOH}$ solution; the transphilic (TPI) fraction

8 refers to the NOM fraction recovered from the XAD-4 resin by elution with an acetonitrile/water

9 mixture. Solid samples of the NOM fractions were obtained from the respective eluents by

10 freeze-drying.

11

12 The NOM fractions were characterised by determination of their specific $\mathrm{UV}_{254}$ values $\left(\mathrm{SUVA}_{254}\right.$

$13=\mathrm{UV}_{254} / \mathrm{mg} / \mathrm{L}$ of dissolved organic carbon (DOC)) and \% aromatic carbon content. The

14 aromaticity of the samples was determined using solid state ${ }^{13} \mathrm{C}$ nuclear magnetic resonance

15 (NMR) spectroscopy. Details of the procedures used to characterise the NOM fractions have been

16 presented elsewhere (Croué et al., 2000). Details of the NOM fractions used in this work and

17 their relevant characteristics are given in Table 1. For the disinfection experiments, these

18 fractions were individually dissolved in MilliQ (MQ) water at concentrations of $5 \mathrm{mg}$ solid NOM

19 fraction per litre. The DOC concentrations of these solutions were determined by the

20 UV/persulfate oxidation method, using a Shimadzu TOC Analyser TOC-V $\mathrm{V}_{\mathrm{ws}}$.

$22 \quad$ 2.2 Disinfection Experiments

23 The hydrophobic fraction from the Loire River (LR HPO) $\left(5 \mathrm{mg} \mathrm{L}^{-1}\right.$ of NOM sample in MQ

24 water, corresponding to $\left.2.62 \mathrm{mg} \mathrm{L}^{-1} \mathrm{DOC}\right)$ was subjected to chlorination $\left(10 \mathrm{mg} \mathrm{L}^{-1} \mathrm{Cl}_{2}\right)$ and 
1 chloramination (preformed chloramine, mass ratio of $\mathrm{Cl}_{2}: \mathrm{N}=4: 1,10 \mathrm{mg} \mathrm{L}^{-1}$ as total $\mathrm{Cl}_{2}$ ) in the

2 presence of added bromide $\left(300 \mu \mathrm{g} \mathrm{L}^{-1}\right)$ and iodide $\left(50 \mu \mathrm{g} \mathrm{L}^{-1}\right)$ ions. Relatively high chlorine and

3 chloramine doses were used in these experiments to ensure that the disinfectant is always in

4 excess, which will result in significant TOX formation. The experiments were carried out at $20^{\circ} \mathrm{C}$

5 and $50^{\circ} \mathrm{C}$, for 48 hours, at $\mathrm{pH} 7$ for chlorination and $\mathrm{pH} 8$ for chloramination, using phosphate

6 buffer $(10 \mathrm{mM})$. Chlorination experiments were carried out at $\mathrm{pH} 7$ to simulate the commonly

7 used $\mathrm{pH}$ in chlorination practices (White, 1999), and since it is the $\mathrm{pH}$ used in the Standard

8 Method for determination of trihalomethane formation potential (Clesceri et al., 1998). A higher

$9 \mathrm{pH}$ was used in the chloramination experiments to ensure that monochloramine was the active

10 species during chloramination, and to minimise the decomposition of monochloramine (Symons

11 et al., 1998). The expected difference in the formation of disinfection by-products between

12 chlorination and chloramination would have been enhanced if $\mathrm{pH} 8$ was used in chlorination

13 experiments (Reckhow and Singer, 1985). Since the comparison of the two oxidants did not

14 represent the major objective of this work, conducting chlorination at $\mathrm{pH} 8$ was not considered.

15 In each experiment, at various times up to $48 \mathrm{hr}$, the residual chlorine in a subsample of the

16 reaction solution was quenched with aqueous sodium sulfite solution, and the sample was then

17 analysed for halogen-specific TOX and THMs.

19 A separate set of chloramination experiments was carried out, using all 9 NOM samples, in

20 which the concentration of iodide ion was varied from 50 to $300 \mu \mathrm{g} \mathrm{L}^{-1}$ (0.39 to $\left.2.36 \mu \mathrm{M}\right)$, while

21 the concentration of bromide ion was kept constant at $300 \mu \mathrm{g} \mathrm{L}^{-1}(3.75 \mu \mathrm{M})$. Another set of

22 chloramination experiments was carried out, using 7 of the 9 NOM samples, in which the

23 concentration of bromide ion was varied from 32 to $190 \mu \mathrm{g} \mathrm{L}^{-1}$ ( 0.40 to $2.40 \mu \mathrm{M}$ i.e. equal molar 
1 concentrations to $50-300 \mu \mathrm{g} \mathrm{L}^{-1}$ iodide ion), while the concentration of iodide ion was kept

2 constant at $475 \mu \mathrm{g} \mathrm{L}^{-1}$ (3.74 $\mu \mathrm{M}$ i.e. equal molar concentration to $300 \mu \mathrm{g} \mathrm{L}^{-1}$ bromide ion). These

3 chloramination experiments were all performed at $20^{\circ} \mathrm{C}$ and $\mathrm{pH}$ 8. Relatively high concentrations

4 of bromide and iodide ions were used in these experiments to represent source waters that contain

5 high concentrations of these ions, where significant formation of brominated and iodinated DBPs

6 are expected (Richardson, 2007). Sampling for the analysis of halogen-specific TOX in these

7 experiments was carried out only at the end of the 48-hour experimental period, after quenching

8 with sodium sulfite.

\section{$10 \quad 2.3 \quad$ Chlorine and Chloramine Measurements}

11 Chlorine and chloramine $\left(\mathrm{NH}_{2} \mathrm{Cl}\right)$ were analysed using the $N, N$-diethylphenylene-1,4-diamine

12 (DPD) colorimetric method (Ventresque et al., 1990). For free chlorine determination, $250 \mu \mathrm{L}$ of

13 a pH 6.8 phosphate buffer solution $\left(24 \mathrm{~g} \mathrm{~L}^{-1} \mathrm{Na}_{2} \mathrm{HPO}_{4}\right.$ and $46 \mathrm{~g} \mathrm{~L}^{-1} \mathrm{KH}_{2} \mathrm{PO}_{4}$, with added $0.8 \mathrm{~g} \mathrm{~L}^{-1}$

14 disodium EDTA and $0.02 \mathrm{~g} \mathrm{~L}^{-1} \mathrm{HgCl}_{2}$ ) was mixed with $250 \mu \mathrm{L}$ of aqueous DPD solution (2 mL

$15 \mathrm{~L}^{-1}$ concentrated $\mathrm{H}_{2} \mathrm{SO}_{4} ; 0.2 \mathrm{~g} \mathrm{~L}^{-1}$ disodium EDTA; $1.1 \mathrm{~g} \mathrm{~L}^{-1}$ anhydrous $N, N$-diethylphenylene-

16 1,4-diamine) and $5 \mathrm{~mL}$ of sample. The absorbance of the resulting solution was then measured at

$17510 \mathrm{~nm}$ using a SAFAS 320 spectrophotometer. For total chlorine (chloramine) determination, a

18 similar procedure was followed, except that potassium iodide ( $\sim 50 \mathrm{mg}$ per sample) was added to

19 the solution prior to measurement of its absorbance.

\section{$21 \quad 2.4 \quad$ Halogen-Specific TOX Analysis}

22 The analysis of halogen-specific TOX was based on the method developed by Hua and Reckhow 23 (2006) with minor modifications. The sample for TOX analysis was firstly acidified to $\mathrm{pH} 2$ and 
1 enriched through adsorption onto an activated carbon column using a Dohrmann ${ }^{\circledR}$ AD-3

2 Adsorption Module. The activated carbon was then placed in a quartz sample boat and introduced

3 into the combustion chamber of a Dohrmann ${ }^{\circledR}$ DX20 TOX Analyser. The activated carbon

4 sample was combusted in the presence of oxygen for 10 minutes at $1000^{\circ} \mathrm{C}$. The hydrogen halide

5 gases produced were collected in MQ water by way of a custom-made absorber. The MQ water

6 was then analysed for $\mathrm{Cl}^{-}, \mathrm{Br}^{-}$, and $\mathrm{I}^{-}$using a Dionex ${ }^{\circledR} \mathrm{DX} 400$ ion chromatograph with

7 conductimetric detection and an ASRS Ultra II Anion Self-Regenerating Suppressor. For the

8 analysis of $\mathrm{Cl}^{-}$and $\mathrm{Br}^{-}$, an $\mathrm{AS} 9-\mathrm{HC}$ column (Dionex ${ }^{\circledR}$ ) was used with $9 \mathrm{mM} \mathrm{Na}_{2} \mathrm{CO}_{3}$ solution as

9 mobile phase. For the analysis of $\mathrm{I}^{-}$, an AS11 column (Dionex ${ }^{\circledR}$ ) was used with $20 \mathrm{mM} \mathrm{NaOH}$

10 solution as mobile phase. The concentrations of $\mathrm{Cl}^{-} \mathrm{Br}^{-}$, and $\mathrm{I}^{-}\left(\mathrm{in} \mu \mathrm{g} \mathrm{\textrm {L } ^ { - 1 }}\right.$ ) obtained from the ion

11 chromatographic (IC) analysis were used to calculate the sample concentration of $\mathrm{TOCl}$ (as $\mu \mathrm{g} \mathrm{\textrm {L } ^ { - }}$

$12{ }^{1} \mathrm{Cl}^{-}$), $\operatorname{TOBr}\left(\right.$ as $\mu \mathrm{g} \mathrm{L}^{-1} \mathrm{Br}^{-}$), and TOI (as $\mu \mathrm{g} \mathrm{L}^{-1} \mathrm{I}^{-}$), respectively, taking into account the

13 concentration factors from the initial sample to the absorber solution. Where the concentration of

14 TOX is given as a $\mathrm{Cl}$ equivalent concentration $\left(\mu \mathrm{g} \mathrm{L}^{-1} \mathrm{Cl}\right)$, it refers to the sum of the molar

15 concentrations of $\mathrm{TOCl}, \mathrm{TOBr}$, and TOI, multiplied by the atomic mass of $\mathrm{Cl}$.

\section{$17 \quad 2.5 \quad$ THMs Analysis}

18 THMs were extracted from the samples by headspace extraction (Dani HSS 3950 headspace

19 sampler), and analysed using gas chromatography (Varian 3300) with an electron capture

20 detection (HS /GC-ECD) (Hureiki et al., 1994). GC separation of THMs was carried out using

21 high purity nitrogen as the carrier gas and a DB-624 megabore capillary column (J\&W; $30 \mathrm{~m} \mathrm{X}$

$220.53 \mathrm{~mm}$, film thickness $0.25 \mu \mathrm{m})$. 


\section{Results and Discussion}

\section{$2 \quad 3.1 \quad$ Validation of the Halogen-Specific TOX Analytical Method}

3 The analysis of halogen-specific TOX was carried out according to the method developed by Hua

4 and Reckhow (2006), with minor modifications to adapt to the instrument and material

5 availability in our laboratory. The recovery of the method was evaluated by determination of the

6 recoveries of several model compounds containing chlorine, bromine, and iodine. These model

7 compounds were bromoform, dichloroacetonitrile, trichloroacetic acid, 2,4,6-tribromophenol, 4-

8 iodophenol and iodoacetic acid. The recoveries of these compounds were studied in a

9 concentration range of 20 to $100 \mu \mathrm{g} \mathrm{L}^{-1}$ in the aqueous samples, which corresponds to a

10 concentration range of 100 to $500 \mu \mathrm{g} \mathrm{L}^{-1}$ in the IC samples, due to the five fold concentration

11 factor in the method. All analyses were conducted in duplicate. Good recoveries, between 85 to

$12109 \%$, were obtained in the present study, comparing well with analytical recoveries reported for

13 halogen-specific TOX by other researchers (Hua and Reckhow, 2006; Echigo et al., 2000;

14 Oleksy-Frenzel et al., 2000).

16 Matrix effects were not observed in the analysis of halogen-specific TOX using the modified

17 method. Good precision of the method was demonstrated, with \% RSD (\% Relative Standard

18 Deviation $=100 \times$ [standard deviation $/$ mean] $)$ values of five replicates analysis ranging from $2-$

$199 \%$. Low detection limits for the ion chromatographic determination of halides were obtained.

20 Detection limits of $5 \mu \mathrm{g} \mathrm{L}^{-1}, 2 \mu \mathrm{g} \mathrm{L} \mathrm{L}^{-1}$, and $2 \mu \mathrm{g} \mathrm{L}^{-1}$ were achieved for the analysis of chloride, 21 bromide, and iodide, respectively. 
1 A hydrophobic fraction isolated from the Loire River (LR HPO) was subjected to chlorination

$2\left(10 \mathrm{mg} \mathrm{L}^{-1} ; \mathrm{pH} 7, \mathrm{DOC}=2.62 \mathrm{mg} \mathrm{C} \mathrm{L}^{-1}\right)$ and chloramination $\left(10 \mathrm{mg} \mathrm{L}^{-1}\right.$ as total $\left.\mathrm{Cl}_{2} ; \mathrm{pH} 8\right)$ in the 3 presence of bromide $\left(300 \mu \mathrm{g} \mathrm{L}^{-1}\right)$ and iodide $\left(50 \mu \mathrm{g} \mathrm{L}{ }^{-1}\right)$ ions for 48 hours. The concentrations of

4 halogen-specific TOX and THMs in these samples were measured. Figures 1 and 2 show the



6 the chlorination and chloramination experiments, respectively, while Figure 3 shows the

7 production of THMs in both experiments. Table 2 presents the specific yield of halogen-specific

8 TOX and the disinfectant demand after 48 hours contact time for both chloramination and

9 chlorination, as well as the ratio of TOX to disinfectant demand. Separate chlorination and

10 chloramination experiments in the presence of iodide ion only $\left(200 \mu \mathrm{g} \mathrm{L}^{-1}\right)$ were carried out using

11 SR HPOA, in order to study the effect of chlorine and chloramine dose on the formation of TOI.

12 Various doses of chlorine and chloramine between 1 and $10 \mathrm{mg} \mathrm{Cl}_{2} \mathrm{~L}^{-1}$ were used, and only the

13 concentration of TOI was measured in these samples. Table 3 gives the TOI formation at 48 -hour

14 contact time for this set of experiments.

$16 \mathrm{TOCl}$ and $\mathrm{TOBr}$ were detected and quantified in both chloramination and chlorination

17 experiments (Figures 1 and 2, Table 2). In contrast, TOI was always formed in chloramination

18 experiments (see Tables 2 and 3), but only formed in chlorination experiments where the chlorine

19 doses were less than $10 \mathrm{mg} \mathrm{L}^{-1}$ (Table 3 ). The results presented in Table 3 demonstrate that the

20 concentration of chlorine significantly affects the formation of TOI, whereas the concentration of

21 chloramine has little effect on the concentration of TOI. In this experiment, at high chlorine

22 concentration of $10 \mathrm{mg} \mathrm{L}^{-1}$, where the initial molar ratio of chlorine to iodide was 90 , excess

23 chlorine was likely to have oxidised all iodide ion to HOI, and then further oxidised the HOI to 
1 iodate. Unlike chlorine, chloramine is only able to oxidise iodide ion to HOI, which is then

2 available for reactions with NOM (Bichsel and von Gunten, 1999) to form TOI. In this case,

3 since chloramine was always in excess compared to iodide, the chloramine concentration had no

4 effect on the amount of TOI formed (Table 3).

6 In both chlorination and chloramination, TOCl was the dominant TOX produced (Table 2). In the

7 chlorination experiments, $\mathrm{TOCl}$ accounted for $77 \%$ of TOX on a molar concentration basis, while

8 the corresponding value for chloramination was $88 \%$. The high proportion of TOCl formed is

9 associated with the high disinfectant dose used in these experiments relative to the typical

10 chlorine doses used in the field. With higher iodide ion concentrations, chloramination was found

11 to result in TOI formation higher than TOCl formation (see Section 3.4).

12

13 Chloramination produced significantly less TOX and THMs than chlorination (Table 2, Figure

143 ). For a 48 -hour contact time, chloramination resulted in a $72 \%$ lower concentration of TOCl

15 and a 93\% lower concentration of TOBr than chlorination (Table 2), which corresponds to an

16 overall TOX (TOCl + TOBr only) reduction of $67 \%$ upon chloramination. The final

17 concentration of total THMs was reduced by $95 \%$ upon chloramination (Figure 3). These results

18 are consistent with other reported studies (e.g. Richardson, 2003; Wu et al., 2003; Richardson et

$19 a l ., 2002)$, where chloramine has been found to produce less DBPs than chlorine, due to the lower

20 reactivity of chloramine.

22 Numerous studies have reported that identified DBPs, such as THMs and HAAs, account for only

23 a fraction of TOX (e.g. Richardson, 2003; Zhang et al., 2000; Symons et al., 1998). This was also

24 observed in the chlorination and chloramination of LR HPOA. In the chloramination experiments 
1 at $20^{\circ} \mathrm{C}$, THMs represented only $7 \%$ of TOX, while, in chlorination, $47 \%$ of TOX could be

2 accounted for by THMs. The proportions of THMs in TOX were lower in the chloramination

3 experiments due to the relative oxidising strengths of chlorine versus chloramine. As a stronger

4 oxidant, chlorine, in the form of $\mathrm{HOCl}$, reacts with NOM mainly through oxidation reactions,

5 producing cleavage by-products such as THMs (Li et al., 2002). Chloramine, however, is a

6 weaker oxidant than chlorine. The formation of DBPs in chloramination is thought to be a result

7 of reactions between $\mathrm{NOM}$ and small amounts of $\mathrm{HOCl}$ present in equilibrium with chloramine

8 (Duirk et al., 2002; Cowman and Singer, 1996), as well as through direct reaction of chloramine

9 with NOM (Duirk et al., 2002). Since there are less reactive species in a chloraminated system,

10 the formation of cleavage by-products, such as THMs, is less favoured, and the formation of by-

11 products of higher molecular weight is preferred (Johnson and Jensen, 1986). Therefore, the

12 THMs form only a small percentage of the TOX measured in chloraminated samples.

13

14 The relative oxidizing strength and the reactivity of chlorine and chloramine were also reflected

15 in the kinetics of the formation of TOX and THMs. In chlorination, 35\% of TOX produced after

1648 hours was formed in the first 30 minutes, while the corresponding value for THM formation at

17 the same time was $30 \%$. In chloramination, 55\% of the total TOX produced was formed in the

18 first 30 minutes, and the corresponding value for THM formation was $15 \%$. These results

19 demonstrate that chloramination favours the formation of non-THMs halogenated by-products,

20 and that the formation of THMs during chloramination would only be the result of reactions

21 between $\mathrm{NOM}$ and residual free chlorine $(\mathrm{HOCl})$ that is present in equilibrium with chloramine

$22\left(\mathrm{NH}_{2} \mathrm{Cl}\right)$. 
$1 \quad 3.3 \quad$ The Effect of Temperature on the Formation of TOX in Chlorination and Chloramination

3 In order to evaluate the influence of temperature on the formation of halogen-specific TOX,

4 chlorination and chloramination experiments with LR HPO NOM were performed at $20^{\circ} \mathrm{C}$ and

$550^{\circ} \mathrm{C}$. The concentrations of halogen-specific TOX formed at these temperatures are presented in

6 Table 2. In both chlorination and chloramination, higher concentrations of halogen-specific TOX

7 were formed at the higher temperature, which was expected, since an increase in temperature has

8 been associated with a higher rate and a greater extent of formation of DBPs (e.g. Carlson and

9 Hardy, 1998; Engerholm and Amy, 1983). Further data observation showed that increasing the

10 temperature from $20^{\circ} \mathrm{C}$ to $50^{\circ} \mathrm{C}$ did not have a significant effect on the proportions of $\mathrm{TOCl}$ and

$11 \mathrm{TOBr}$ in both chlorination and chloramination experiments. Therefore, the proportions of TOX in

12 chlorination and chloramination are not influenced by temperature, rather, they appear to be

13 primarily determined by the relative amounts of the halogen species in the system.

14

15 Furthermore, although the concentrations of halogen-specific TOX increased with increasing

16 temperature, the amount of halogen-specific TOX produced per mg of disinfectant consumed was

17 found to be higher at $20^{\circ} \mathrm{C}$ than at $50^{\circ} \mathrm{C}$, for both chlorination and chloramination experiments

18 (Table 2). This demonstrates that the proportion of the disinfectant used in non-TOX forming

19 reactions, e.g. oxidation reactions forming non-halogenated DBPs, increases when the

20 temperature increases.

$22 \quad 3.4 \quad$ The Effect of Iodide Ion and Bromide Ion on the Distribution of TOX in 
1 The effect of iodide ion and bromide ion concentrations on the formation and distribution of

2 halogen-specific TOX upon chloramination of a selection of NOM isolates was investigated.

3 NOM fractions were separately subjected to chloramination $\left(10 \mathrm{mg} \mathrm{L}^{-1}\right.$ as total $\left.\mathrm{Cl}_{2} ; \mathrm{pH} 8\right)$ for 48

4 hours and for different concentrations of iodide and bromide ions: a constant iodide ion

5 concentration of $3.74 \mu \mathrm{M}\left(475 \mu \mathrm{g} \mathrm{L}^{-1}\right)$, with initial concentrations of bromide ion varying from

$6 \quad 0.40 \mu \mathrm{M}$ to $2.40 \mu \mathrm{M}$ (32 to $\left.190 \mu \mathrm{g} \mathrm{L}^{-1}\right)$; and a constant bromide ion concentration of $3.75 \mu \mathrm{M}$

$7 \quad\left(300 \mu \mathrm{g} \mathrm{L}^{-1}\right)$, with initial concentrations of iodide ion varying from 0.39 to $2.36 \mu \mathrm{M}$ (50 to $300 \mu \mathrm{g}$

$8 \mathrm{~L}^{-1}$ ). Figure 4 shows, as an example, a typical halogen-specific TOX distribution obtained from

9 the LR HPOA isolate, illustrating the effect of varying bromide ion concentrations (Figure 4a)

10 and iodide ion concentrations (Figure 4b).

12 In these experiments, for all conditions, TOCl and TOI were the dominant TOX produced, while

13 TOBr was produced at concentrations more than ten-fold lower than those of TOCl and TOI. The

14 average concentration of $\mathrm{TOBr}$ formed was approximately $1.5 \mu \mathrm{g} \mathrm{eq} \mathrm{Cl} / \mathrm{mg} \mathrm{C}$ when the initial

15 bromide ion concentration was $300 \mu \mathrm{g} \mathrm{L}^{-1}$. Although the concentrations of TOBr increased

16 slightly with increasing initial bromide ion concentration, the bromine incorporation (percentage

17 of the initial bromide ion incorporated into $\mathrm{TOBr}$ i.e. $\left.[\mathrm{TOBr}] /\left[\mathrm{Br}^{-}\right]_{\text {initial }} \times 100\right)$ decreased, for all

18 NOM isolates (Table 4). The maximum bromine incorporation was $18 \%$, which was achieved in

19 the chloramination of SPR HPOA with an initial bromide ion concentration of $32 \mu \mathrm{g} \mathrm{L}^{-1}$. The

20 change in the initial concentration of bromide ion was found to have no significant effect on the

21 concentrations of TOCl, TOI, and TOX. 
1 High linear correlations were observed between the production of TOI and the initial iodide ion

2 concentration $\left(r^{2}=0.95-0.99\right)$ (see Figure $4 b$ for results from LR HPOA). As a result of the

3 increase in TOI concentration with increasing initial iodide ion concentration, the overall TOX

4 concentration also increased. Unlike the observations from varying the initial bromide ion

5 concentration, iodine incorporation (percentage of the initial iodide ion incorporated into TOI i.e.

$\left.6[\mathrm{TOI}] /\left[\mathrm{I}^{-}\right]_{\text {initial }} \times 100\right)$ was found to increase as the initial iodide ion concentration increased,

7 varying from 8 to $64 \%$, depending on the NOM isolate and the initial iodide ion concentration

8 (Table 4). At constant bromide ion concentration $\left(300 \mu \mathrm{g} \mathrm{L}^{-1}\right), \mathrm{TOBr}$ production was not

9 significantly affected by the increase in initial iodide ion concentration (Figure 4b).

11 The observed lower proportion of $\mathrm{TOBr}$ compared to TOI, and the lower bromine incorporation

12 compared to iodine incorporation in chloramination can be explained by a low concentration of

$13 \mathrm{HOBr}$ in the system. In chloramination, a variety of bromine species can be formed, but not all

14 contribute to DBP formation. $\mathrm{NH}_{2} \mathrm{Cl}$ reacts with bromide ion to form bromochloramine as shown

15 by the following equation (Gazda et al., 1993):

$$
\mathrm{NH}_{2} \mathrm{Cl}+\mathrm{Br}^{-} \rightleftharpoons \mathrm{NHBrCl}
$$

17 Small amounts of $\mathrm{HOBr}$ could be produced by the reaction between bromide ion and $\mathrm{HOCl}$,

18 present in equilibrium with $\mathrm{NH}_{2} \mathrm{Cl}$. The $\mathrm{HOBr}$ formed could then react with $\mathrm{NH}_{2} \mathrm{Cl}$, as well as

$19 \mathrm{NH}_{3}$ that results from chloramine decay, to produce $\mathrm{NH}_{2} \mathrm{Br}$ and other bromamine species, as

20 shown by the following equations (Gazda et al., 1993; Wajon and Morris, 1980):

$$
\begin{array}{lll}
\mathrm{HOBr}+\mathrm{NH}_{2} \mathrm{Cl} & \rightleftharpoons & \begin{array}{l}
\mathrm{NHBrCl} \text { and } \mathrm{NBr}_{2} \mathrm{Cl} \\
\mathrm{HOBr}+\mathrm{NH}_{3}
\end{array} \\
\mathrm{NH}_{2} \mathrm{Cl}+\mathrm{NHBr}_{2} \mathrm{Br}+\mathrm{H}_{2} \mathrm{O} \\
\mathrm{NH}_{2} \mathrm{Cl}+\mathrm{NH}_{2} \mathrm{Br} & \rightleftharpoons & \mathrm{NHBrCl} \text { and } \mathrm{NBr}_{2} \mathrm{Cl} \\
& & \mathrm{NHBrCl}
\end{array}
$$


1 In addition, $\mathrm{HOBr}$ could also be consumed in reactions with iodide and HOI, which would reduce

2 its availability to react with $\mathrm{NOM}$. $\mathrm{HOBr}$ could induce the oxidation of iodide ion in the same

3 manner as $\mathrm{HOCl}$ (Hua et al., 2006), and it has been reported to oxidise iodide to HOI through an

4 IBr intermediate (Troy and Margerum, 1991).

6 Bromamines and bromochloramine do not react with NOM as readily as $\mathrm{HOBr}$, and their

7 reactivities in the formation of DBPs are largely unknown (Symons et al., 1998). Therefore, the

8 likely formation of bromamines and bromochloramine in chloramination would limit the steady

9 state concentration of active bromine species, and thus the formation of $\mathrm{TOBr}$.

11 In contrast to bromide, $\mathrm{NH}_{2} \mathrm{Cl}$ oxidizes iodide ion into hypoiodous acid, which is not further

12 oxidized by $\mathrm{NH}_{2} \mathrm{Cl}$ (Bichsel and von Gunten, 1999). $\mathrm{HOI}$ is then available for fast reactions with

13 NOM, leading to iodinated DBPs (Bichsel and von Gunten, 2000). Even though HOI is also

14 involved in oxidation reactions with formation of iodide, iodide is continuously reoxidised into

15 HOI, which favours the substitution reactions and explains the high incorporation of iodide into

16 NOM as TOI.

\subsection{The Influence of NOM Characteristics on the Formation of TOX in Chloramination}

19 In chlorination, aromatic structures within NOM have been reported to be especially reactive

20 with chlorine in producing DBPs, and significant correlations have been observed between

21 aromaticity (as indicated by $\mathrm{UV}_{254}$ or $\mathrm{SUVA}_{254}$, and \% aromatic C) and DBP formation (Croué $e t$

22 al., 2000; Wu et al., 2000; Reckhow et al., 1990). In light of this, correlations between the

23 production of organohalides (TOX as $\mu \mathrm{g} \mathrm{L}^{-1} \mathrm{Cl}$, TOCl as $\mu \mathrm{g} \mathrm{L}^{-1} \mathrm{Cl}$, TOBr as $\mu \mathrm{g} \mathrm{L}^{-1} \mathrm{Br}$, and TOI 
1 as $\left.\mu \mathrm{g} \mathrm{L}^{-1} \mathrm{I}\right)$ in chloramination and the characteristics of $\mathrm{NOM}\left(\mathrm{SUVA}_{254}\right.$ and $\%$ aromatic $\mathrm{C}$ ) were 2 examined in the present study. Data from the chloramination experiments using $300 \mu \mathrm{g} \mathrm{L}^{-1}$

3 bromide ion and $50 \mu \mathrm{g} \mathrm{L}^{-1}$ iodide ion was used for this purpose. The correlation coefficient

4 values obtained for the different linear correlations evaluated in the present study are presented in

5 Table 5. Good linear correlations were observed for TOCl and $\mathrm{TOBr}$ with $\mathrm{SUVA}_{254}$ and \%

6 aromatic $\mathrm{C}$, indicating that aromatic moieties play a significant role in the formation of $\mathrm{TOCl}$ and

7 TOBr. Similar correlations were also obtained for TOX since TOCl was the major contributor to

8 TOX. Other researchers have reported that a linear correlation exists between $\mathrm{SUVA}_{254}$ and the

9 formation of TOX in chlorination (Rostad et al., 2000; Krasner et al., 1996) and chloramination

10 (Wu et al., 2003), and also between TOX and \% aromatic C in chloramination (Wu et al., 2003).

11 Wu et al. (2003) reported $\mathrm{r}^{2}=0.69$ for the correlation between aromatic $\mathrm{C}$ and TOX formation

12 from chloramination of humic substance samples. Rostad et al. (2000) reported $r^{2}=0.67$ for the

13 correlation of 7-day TOX formation potential and $\mathrm{SUVA}_{254}$ in the chlorination of tertiary treated

14 wastewaters from Arizona, USA. Krasner et al. (1996) obtained $\mathrm{r}^{2}=0.93$ for the correlation of

15 specific yield of TOX and $\mathrm{SUVA}_{254}$ in the chlorination of NOM fractions from Apremont

16 reservoir, France. This data indicates that the fraction of NOM represented by $\mathrm{SUVA}_{254}$ and $\%$

17 aromatic $\mathrm{C}$ plays an important role in the formation of overall TOX, in both chlorination and

18 chloramination.

19

20 For a low iodide ion concentration of $50 \mu \mathrm{g} \mathrm{L}^{-1}$ (i.e. $0.39 \mu \mathrm{M}$ ), TOI formation was low for all

21 NOM isolates, and no linear correlation was observed between TOI and $\mathrm{SUVA}_{254}$ or $\%$ aromatic

$22 \mathrm{C}$ (Table 5). For this condition, the character of NOM was not a predominant factor influencing

23 the formation of TOI. As it was shown previously in Section 3.4, the concentrations of TOI 
1 linearly increased with increasing iodide ion concentration i.e. with increasing concentration of

2 reactive iodine species. Linear regression was fitted to graphs of [TOI] vs. initial $\left[\mathrm{I}^{-}\right]$for all NOM

3 isolates. Different values of the slope for this correlation were obtained and the following trend

4 was observed: the higher the $\mathrm{SUVA}_{254}$ value, the higher the reactivity of NOM and the higher the

5 value of [TOI] vs. $\left[\mathrm{I}^{-}\right]$slope. Fitting a logarithmic regression to the data points showed a

6 relationship between the slope of TOI formation and SUVA $_{254}$ values, with a significant $\mathrm{r}^{2}$ value

7 of 0.875 (Figure 5). Furthermore, a good linear correlation was also obtained between TOI

8 concentrations and $\mathrm{SUVA}_{254}$ values $\left(\mathrm{r}^{2}=0.983\right.$, results not shown $)$ for the experiments conducted

9 using high initial iodide ion concentration of $475 \mu \mathrm{g} \mathrm{L}^{-1}$ (i.e. $3.74 \mu \mathrm{M}$ ) and various initial

10 bromide ion concentrations. This means that aromatic moieties in NOM, as indicated by

11 SUVA $_{254}$, are major reactive sites for the production of TOI in chloramination of iodide-

12 containing waters, which is in accordance with the general findings of NOM reactivity with

13 halogenated oxidants. Bichsel and von Gunten (2000) showed that phenolic moieties (but not

14 carbonyl moieties) could account for the observed reactivity of HOI with NOM. The present

15 study further demonstrates that the aromaticity of NOM significantly affects the formation of

16 DBPs in general, and halogen-specific TOX (TOCl, TOBr, and TOI) in particular.

\section{Conclusions}

19 The formation of halogen-specific TOX upon chlorination and chloramination of NOM isolates

20 in the presence of bromide and iodide ions was studied and the following conclusions were made:

21 - Chloramination produced significantly less TOX and THMs than chlorination.

22 - In both chlorination and chloramination, $\mathrm{TOCl}$ was the dominant TOX species produced, as a 23 result of the high ratios of $\mathrm{Cl}_{2} / \mathrm{Br}^{-}$and $\mathrm{Cl}_{2} / \mathrm{I}^{-}$used in these experiments. A higher proportion 
1 of $\mathrm{TOCl}$ was observed in chloraminated samples, indicating limited formation of $\mathrm{TOBr}$ in

2 chloramination due to the formation of bromamines instead of $\mathrm{HOBr}$.

- TOI was always produced during chloramination, which is in agreement with the known chemistry of iodine in water treatment. In chlorination, chlorine oxidises iodide through to iodate, limiting the presence of HOI for reactions with NOM to produce TOI. A suitable chlorine dose, sufficient to completely oxidise iodide to iodate, should be utilised for source waters containing iodide, since it will limit the formation of TOI, which is considered to be more harmful than $\mathrm{TOCl}$ and $\mathrm{TOBr}$.

9 - In chlorination, THMs constituted $47 \%$ of TOX, while THMs comprised only $7 \%$ of TOX in 10 chloramination. Although chloramine produced less TOX than chlorine, it formed 11 proportionally more non-THM DBPs. These non-THM DBPs are mostly unknown, corresponding to unknown health risks. The results of this study highlight that better

13 understanding and estimation of the health risks associated with chloramination DBPs are 14 needed.

- The formation of TOI in chloramination increased as the initial iodide ion concentration increased. A maximum of $\sim 60 \%$ of the initial iodide ion was incorporated into NOM and measured as TOI. Iodine incorporation into NOM was consistently higher than bromine incorporation, although the molar concentrations of initial iodide ion were lower than bromide ion. Competitive reactions between bromine and iodine species were found to favour the formation of $\mathrm{HOI}$ and thus TOI, rather than $\mathrm{TOBr} . \mathrm{NH}_{2} \mathrm{Cl}$ reacts with iodide to

21 produce only $\mathrm{HOI}$, which then reacts with $\mathrm{NOM}$ to produce TOI; while $\mathrm{NH}_{2} \mathrm{Cl}$ reacts with 22 bromide forming $\mathrm{HOBr}$, as well as other bromine species such as bromamine and bromochloramine, which have little contribution to the formation of $\mathrm{TOBr}$, and $\mathrm{HOBr}$ could 
1 also be consumed in reactions with iodide to produce HOI, rather than in reactions with

2 NOM to produce TOBr. This study shows that the presence of bromide and iodide ions

3 significantly affected the extent of TOX formation, as well as the distribution of TOX

4 species. Therefore, inorganic precursors of DBPs also need to be seriously considered in

5 efforts to minimise DBP formation and risks.

6 - This study demonstrates that high concentrations of TOI could be formed, and that the

7 formation of TOI is favoured, in chloramination. Recent research has shown that iodinated

8 DBPs are more toxic and pose a greater health risk than chlorinated and brominated DBPs.

9 Since chloramine also has the potential to form proportionally higher unknown DBPs, water

10 utilities need to carefully balance the risks and benefits of using chloramine as an alternative

11 disinfectant to satisfy guideline values for THMs.

12

- Good linear correlations between the aromatic character of the NOM isolates SUVA $_{254}$ and

$13 \%$ aromatic $\mathrm{C}$ ) and the formation of $\mathrm{TOX}, \mathrm{TOCl}$, and $\mathrm{TOBr}$ in chloramination were observed,

14 indicating that aromatic moieties play an important role in the formation of TOX, TOCl, and

$15 \mathrm{TOBr}$ in chloramination. For all NOM isolates, the formation of TOI linearly increased with

16 increasing initial iodide ion concentration and the slopes of linear regression of [TOI] $v s$.

17 initial $\left[\mathrm{I}^{-}\right]$were well correlated to the aromatic character of NOM $\left(\mathrm{SUVA}_{254}\right.$ and $\%$ aromatic

18 C). Hence, the aromaticity of NOM also affected the formation of TOI in chloramination.

19 Based on these results, it is recommended that removal of the aromatic fraction of NOM

20 during water treatment is maximised, in order to limit the formation of TOX in chlorination

21 and chloramination. 


\section{Acknowledgements}

2 The work described in this paper was carried out during a research visit at the Laboratoire de

3 Chimie et Microbiologie de l'Eau (LCME). The authors wish to acknowledge LCME for funding

4 the project, and the financial support provided by the Curtin Water Quality Research Centre, the

5 Cooperative Research Centre for Water Quality and Technology (Travel Grant and Postgraduate

6 Scholarship), the International Humic Substances Society (Training Bursary), and Curtin

7 University of Technology (International Postgraduate Research Scholarship). The authors also

8 thank: David Reckhow and Guanghui Hua of the University of Massachusetts, USA, for

9 assistance in halogen-specific TOX analytical method development.

\section{References}

13 Baribeau, H., Prévost, M., Desjardins, R., and Lafrance, P. (2001) Changes in chlorine and DOX 14 concentrations in distribution systems. Journal American Water Works Association 93, 102-14. 15

16 Bichsel, Y. and von Gunten, U. (2000). Formation of iodo-trihalomethanes during disinfection 17 and oxidation of iodide-containing waters. Environmental Science and Technology, 34, 2784182791.

20 Bichsel, Y. and von Gunten, U. (1999) Oxidation of iodide and hypoiodous acid in the

21 disinfection of natural waters. Environmental Science and Technology 33, 4040-4045.

23 Carlson, M. and Hardy, D. (1998) Controlling DBPs with monochloramine. Journal American 24 Water Works Association 90, 95-106. 
2 Clesceri, L. S., Greenberg, A. E. and Eaton, A. D. (1998) Standard Methods for the Examination

3 of Water and Wastewater $20^{\text {th }}$ edition, American Public Health Association, Washington DC,

4 USA.

5

6 Cowman, G.A. and Singer, P.C. (1996) Effect of bromide ion on haloacetic acid speciation

7 resulting from chlorination and chloramination of aquatic humic substances. Environmental

8 Science and Technology 30, 16-24.

9

10 Croué, J-P., Korshin, G.V., and Benjamin, M.M. (2000) Characterisation of Natural Organic

11 Matter in Drinking Water. AWWA Research Foundation, USA.

12

13 Diehl, A.C., Speitel, G.E., Symons, J.M., Krasner, S.W., Hwang, C.J., and Barrett, S.E. (2000)

14 DBP formation during chloramination. Journal American Water Works Association 92, 76-90.

15

16 Duirk, S.E., Gombert, B., Choi, J., and Valentine, R.L. (2002) Monochloramine loss in the

17 presence of humic acid. Journal of Environmental Monitoring 4, 85-89.

18

19 Echigo, S., Zhang, X., Minear, R.A., and Plewa, M.J. (2000) Differentiation of total organic

20 brominated and chlorinated compounds in total organic halide measurement: a new approach

21 with ion-chromatographic technique. IN: Barret SE, Krasner SW, and Amy GL (eds.) Natural

22 Organic Matter and Disinfection By-products. American Chemical Society, USA, 330-342. 
1 Engerholm, B. and Amy, G. (1983) A predictive model for chloroform formation from humic

2 acid. Journal American Water Works Association 75, 418-423.

4 Gazda M., Dejarmi L.E., Choudhury T.K., Cooks R.G., and Margerun D.E. (1993) Mass

5 spectrometric evidence for the formation of bromochloramine and $\mathrm{N}$-Bromo- $\mathrm{N}$ -

6 chloromethylamine in aqueous solution. Environmental Science and Technology 27, 557-561.

7

8 Hua, G. and Reckhow, D.A. (2007) Characterisation of disinfection byproduct precursors based

9 on hydrophobicity and molecular size. Environmental Science and Technology, 41, 3309-3315.

10

11 Hua, G. and Reckhow, D.A. (2006) Determination of TOCl, TOBr, and TOI in drinking water by 12 pyrolysis and off-line ion chromatography. Analytical and Bioanalytical Chemistry 384, 495-504.

13

14 Hua, G., Reckhow, D.A., and Kim, J. (2006) Effect of bromide and iodide ions on the formation

15 and speciation of disinfection byproducts during chlorination. Environmental Science and

16 Technology 40, 3050-3056.

17

18 Hureiki L., Croué J-P., and Legube, B. (1994) Chlorination studies of free and combined amino

19 acids. Water Research, 12, 2521-2531.

20

21 Johnson, J.D. and Jensen, J.N. (1986) THM and TOX formation: routes, rates, and precursors.

22 Journal American Water Works Association 78, 156-162.

23 
1 Krasner, S.W., Sclimenti, M.J., Chinn, R., Chowdhury, Z.K., and Owen, D.M. (1996) The impact

2 of TOC and bromide on chlorination by-product formation. IN: Minear RA and Amy GL (eds.)

3 Disinfection By-Products in Water Treatment, CRC Press Inc., New York, USA, 59-89.

5 Li, C., Benjamin, M.M., and Korshin, G.V. (2002) The relationship between TOX formation and 6 spectral changes accompanying chlorination of pre-concentrated or fractionated NOM. Water $7 \quad$ Research 36, 3265-3272.

8

9 Oleksy-Frenzel, J., Wischnack, S., and Jekel, M. (2000) Application of ion-chromatography for 10 the determination of the organic-group parameters $\mathrm{AOCl}, \mathrm{AOBr}$, and $\mathrm{AOI}$ in water. Fresenius 11 Journal of Analytical Chemistry 366, 89-94.

12

13 Plewa, M.J., Wagner, E.D., Richardson, S.D., Thruston Jr, A.D., Woo, Y.T., and McKague, A.B. 14 (2004) Chemical and biological characterisation of newly discovered iodoacid drinking water 15 disinfection byproducts. Environmental Science Technology 38, 4713-4722.

17 Pourmoghaddas, H., and Stevens, A.A. (1995) Relationship between trihalomethanes and 18 haloacetic acids with total organic halogen during chlorination. Water Research 29, 2059-2062.

20 Reckhow, D.A., and Singer, P.C. (1985). Mechanisms of organic halide formation during fulvic 21 acid chlorination and implications with respect to preozonation. IN: Jolley RL, Bull RJ, Davis 22 WP, Katz S, Roberts MH, and Jacobs VA (eds.) Water Chlorination: Chemistry, Environmental 23 Impact and Health Effects Volume 5, Lewis Publishers Inc., Chelsea, Michigan, USA, 1229$24 \quad 1257$. 
2 Reckhow, D.A., Singer, P.C., and Malcolm, R.L. (1990) Chlorination of humic materials: by-

3 product formation and chemical interpretations. Environmental Science and Technology 24,

$4 \quad 1655-1664$.

5

6 Richardson, S.D. (2007) Water analysis: Emerging contaminants and current issues. Analytical

7 Chemistry 79, 4295-4324.

8

9 Richardson, S.D. (2003) Disinfection by-products and other emerging contaminants in drinking 10 water. Trends in Analytical Chemistry 22, 666-684.

11

12 Richardson, S.D., Simmons, J.E., and Rice, G. (2002) Disinfection by-products: the next

13 generation. Environmental Science and Technology 36, 198A-205A.

14

15 Rostad, C.E., Martin, B.S., Barber, L.B., Leenheer, J.A., and Daniel, S.R. (2000) Effect of a

16 constructed wetland on disinfection by-products: removal processes and production of

17 precursors. Environmental Science and Technology 34, 2703-2710.

18

19 Symons, J.M., Xia, R., Speitel, G.E., Diehl, A.C., Hwang, C.J., Krasner, S.W., and Barrett, S.E.

20 (1998) Factors affecting disinfection by-product formation during chloramination. AWWA

21 Research Foundation, USA.

22 
1 Troy, R.C. and Margerum, D.W. (1991) Non-metal redox kinetics: Hypobromite and

2 hypobromous acid reactions with iodide and with sulfite and the hydrolysis of bromosulfate.

3 Inorganic Chemistry 30, 3538-3543.

4

5 Ventresque, C., Bablon, G., Legube, B., Jadas-Hecart, A., and Doré, M. (1990) Development of

6 chlorine demand kinetics in a drinking water treatment plant. IN: Jolley RL, Condie LW, Johnson

7 JD, Katz S, Minear RA, Mattice JS, and Jacobs VA (eds.) Water Chlorination: Chemistry,

8 Environmental Impact, and Health Effects Volume 6, Lewis Publishers, Michigan, USA, 715-

9728.

10

11 Wajon, J.E. and Morris, J.C. (1980) Bromamination chemistry: Rates of formation of $\mathrm{NH}_{2} \mathrm{Br}$ and

12 some $N$-bromamino acids. IN: Jolley RL, Brungs WA, Cumming RB, and Jacobs VA (eds.),

13 Water Chlorination: Environmental Impact and Health Effects Volume 3, Ann Arbor Science,

14 Ann Arbor, Michigan, USA, 171-181.

15

16 White, C. (1999) Handbook of Chlorination and Alternative Disinfectants, John Wiley and Sons

17 Inc., New York, USA.

18

19 Wu, W.W., Chadik, P.A., and Delfino, J.J. (2003) The relationship between disinfection by-

20 product formation and structural characteristics of humic substances in chloramination.

21 Environmental Toxicology and Chemistry 22, 2845-2852.

22

23 Wu, W.W., Chadik, P.A., Davis, W.M., Delfino, J.J. and Powell, D.H. (2000) The effect of

24 structural characteristics of humic substances on disinfection by-product formation in 
1 chlorination. IN: Barrett SE, Krasner SW, and Amy GL (eds.), Natural Organic Matter and

2 Disinfection By-Products: Characterisation and Control in Drinking Water, American Chemical 3 Society, New York, USA, 109-121.

4

5 Zhang, X., Echigo, S., Minear, R.A., and Plewa, M.J. (2000) Characterisation and comparison of

6 disinfection by-products of four major disinfectants. IN: Barret SE, Krasner SW, and Amy GL

7 (eds.) Natural Organic Matter and Disinfection By-products. American Chemical Society, USA, $8 \quad 299-314$.

9 


\section{Tables and Figures}

Table 1: NOM fractions and their characteristics

\begin{tabular}{|c|c|c|c|c|}
\hline NOM Source & Fraction & Abbreviation & $\begin{array}{c}\text { SUVA }_{254} \\
\left(\mathrm{~L} \mathrm{mg}^{-1} \mathrm{~m}^{-1}\right)\end{array}$ & $\begin{array}{c}\text { \% Aromatic } \\
\text { Carbon }\end{array}$ \\
\hline Loire River & $\begin{array}{l}\text { Hydrophobic Acid } \\
\text { (HPOA) }\end{array}$ & LR HPOA & 3.1 & 15 \\
\hline Loire River & Hydrophobic (HPO) & LR HPO & 2.9 & 18 \\
\hline Loire River & Transphilic (TPI) & LR TPI & 2.0 & 11 \\
\hline Suwannee River & HPOA & SR HPOA & 4.6 & 26 \\
\hline Ribou Reservoir & HPO & RR HPO & 3.4 & 16 \\
\hline Ribou Reservoir & TPI & RR TPI & 2.1 & 9 \\
\hline Colorado River & HPO & CR HPO & 1.8 & 14 \\
\hline Colorado River & TPI & CR TPI & 1.4 & 10 \\
\hline South Platte River & HPOA & SPR HPOA & 2.9 & 12 \\
\hline
\end{tabular}

Table 2: Specific yield of halogen-specific TOX ( $\mu \mathrm{g}$ as $\mathrm{Cl} / \mathrm{mg} \mathrm{C}$ ) from chlorination $\left(\mathrm{Cl}_{2}\right.$ dose $10 \mathrm{mg}$ $\left.\mathrm{L}^{-1}, \mathrm{pH} 7\right)$ and chloramination $\left(\mathrm{NH}_{2} \mathrm{Cl}\right.$ dose $\left.10 \mathrm{mg} \mathrm{L}^{-1}, \mathrm{pH} 8\right)$ of $\mathrm{LR} \mathrm{HPO}$ at $20^{\circ} \mathrm{C}$ and $50^{\circ} \mathrm{C}\left(\left[\mathrm{Br}^{-}\right]=\right.$ $\left.300 \mu \mathrm{g} \mathrm{L}^{-1} ; \mathrm{I}^{-}\right]=50 \mu \mathrm{g} \mathrm{L}^{-1}, 48$ hours contact time)

\begin{tabular}{|c|c|c|}
\hline & $20^{\circ} \mathrm{C}$ & $\mathbf{5 0}^{\circ} \mathrm{C}$ \\
\hline \multicolumn{3}{|c|}{ CHLORINATION (pH 7, $10 \mathrm{mg} \mathrm{L}^{-1} \mathrm{Cl}_{2}$ ) } \\
\hline $\mathrm{TOCl}$ & 76 & 89 \\
\hline $\mathrm{TOBr}$ & 23 & 34 \\
\hline TOI & \multicolumn{2}{|c|}{ not detected } \\
\hline TOX & 99 & 123 \\
\hline $\mathrm{Cl}_{2}$ demand $\left(\mathrm{mg} \mathrm{L}^{-1}\right)$ & 3.7 & 7.8 \\
\hline $\mathrm{TOX}$ in $\mu \mathrm{g} \mathrm{Cl} / \mathrm{mg} \mathrm{Cl}_{2}$ & 26.8 & 15.8 \\
\hline \multicolumn{3}{|c|}{ CHLORAMINATION (pH 8, $10 \mathrm{mg} \mathrm{L}^{-1} \mathrm{NH}_{2} \mathrm{Cl}$ ) } \\
\hline $\mathrm{TOCl}$ & 22 & 33 \\
\hline $\mathrm{TOBr}$ & 2 & 2 \\
\hline TOI & 1 & 2 \\
\hline TOX & 25 & 37 \\
\hline $\mathrm{NH}_{2} \mathrm{Cl}$ demand $\left(\mathrm{mg} \mathrm{L}^{-1}\right)$ & 0.7 & 3.3 \\
\hline $\mathrm{TOX}$ in $\mu \mathrm{g} \mathrm{Cl} / \mathrm{mg} \mathrm{NHCl}_{2}$ & 35.7 & 11.2 \\
\hline
\end{tabular}


Table 3: TOI formation in chlorination $\left(\mathrm{Cl}_{2}\right.$ dose $\left.10 \mathrm{mg} \mathrm{L}^{-1}, \mathrm{pH} 7\right)$ and chloramination $\left(\mathrm{NH}_{2} \mathrm{Cl}\right.$ dose $10 \mathrm{mg} \mathrm{L}^{-1}, \mathrm{pH}$ 8) of SR HPOA at various disinfectant doses (DOC $=2.9 \mathrm{mg} \mathrm{C} \mathrm{L}^{-1} ;\left[\mathrm{I}^{-}\right]=200 \mu \mathrm{g} \mathrm{L}^{-1}$, $20^{\circ} \mathrm{C}, 48$ hours contact time)

\begin{tabular}{cccc}
\hline \multicolumn{2}{c}{ Disinfectant dose } & Chlorination & Chloramination \\
\hline $\mathbf{m g ~ C l}_{\mathbf{2}} \mathbf{L}^{-\mathbf{1}}$ & $\mathbf{C l}_{\mathbf{2}} / \mathbf{I}$ molar ratio & $\begin{array}{c}\boldsymbol{\mu g} \mathbf{T O I} \text { as } \\
\mathbf{C l} / \mathbf{m g ~ C}\end{array}$ & $\begin{array}{c}\boldsymbol{\mu g} \mathbf{~ T O I} \text { as } \\
\mathbf{C l} / \mathbf{m g ~ C}\end{array}$ \\
\hline 1 & 9 & 9 & 8 \\
2 & 18 & 10 & 10 \\
5 & 45 & 2 & 11 \\
10 & 90 & not detected & 11
\end{tabular}

Table 4: Iodine and bromine incorporation into NOM in chloramination experiments $\left(5 \mathrm{mg} \mathrm{L}^{-1} \mathrm{NOM}\right.$, $\mathrm{NH}_{2} \mathrm{Cl}$ dose $10 \mathrm{mg} \mathrm{L}^{-1}, \mathrm{pH} 8,20^{\circ} \mathrm{C}, 48$ hours contact time)

\begin{tabular}{|c|c|c|c|c|c|c|c|c|}
\hline \multirow[t]{2}{*}{ Sample } & \multicolumn{4}{|c|}{$\begin{array}{c}\text { \% Iodine incorporation } \\
\text { at various initial }\left[\mathrm{I}^{-}\right]\end{array}$} & \multicolumn{4}{|c|}{$\begin{array}{c}\% \text { Bromine incorporation } \\
\text { at various initial }\left[\mathrm{Br}^{-}\right]\end{array}$} \\
\hline & $50 \mu \mathrm{g} \mathrm{L}^{-1}$ & $100 \mu g L^{-1}$ & $200 \mu \mathrm{g} \mathrm{L}^{-1}$ & $300 \mu \mathrm{g} \mathrm{L}^{-1}$ & $32 \mu \mathrm{g} \mathrm{L}^{-1}$ & $63 \mu g \mathrm{~L}^{-1}$ & $126 \mu \mathrm{g} \mathrm{L}^{-1}$ & $190 \mu \mathrm{g} \mathrm{L}^{-1}$ \\
\hline LR HPOA & 30 & 40 & 63 & 56 & 7.8 & 4.6 & 3.3 & 2.8 \\
\hline LR HPO & 11 & 24 & 40 & 45 & nd & nd & nd & nd \\
\hline LR TPI & 24 & 28 & 43 & 62 & 8.1 & 4.7 & 3.3 & 2.4 \\
\hline SR HPOA & 12 & 24 & 64 & 54 & nd & nd & nd & nd \\
\hline RR HPO & 40 & 32 & 47 & 55 & 14 & 8.0 & 4.8 & 3.3 \\
\hline RR TPI & 28 & 26 & 41 & 41 & 12 & 6.4 & 3.8 & 3.0 \\
\hline CR HPO & 10 & 19 & 32 & 29 & 10 & 6.4 & 4.0 & 2.8 \\
\hline CR TPI & 8 & 13 & 17 & 18 & 8.4 & 4.6 & 3 & 2.3 \\
\hline SPR HPOA & 28 & 28 & 45 & 49 & 18 & 10 & 5.6 & 3.8 \\
\hline
\end{tabular}

Table 5: Linear correlation coefficient $\left(\mathrm{r}^{2}\right)$ values for the correlation between overall and specific TOX concentrations and $\mathrm{SUVA}_{254}$ and \% aromatic $\mathrm{C}\left(\mathrm{NH}_{2} \mathrm{Cl}\right.$ dose $10 \mathrm{mg} \mathrm{L}^{-1}, 5 \mathrm{mg} \mathrm{L}^{-1} \mathrm{NOM}$, $50 \mu \mathrm{g} \mathrm{L}^{-1}$ iodide ion, $300 \mu \mathrm{g} \mathrm{L}{ }^{-1}$ bromide ion, $\mathrm{pH} 8$, contact time 48 hours, $20^{\circ} \mathrm{C}$ )

\begin{tabular}{lc}
\hline \multicolumn{1}{c}{ Linear Correlation } & $\mathbf{r}^{2}$ \\
\hline SUVA $_{254}-\mathrm{TOX}$ & 0.711 \\
$\mathrm{SUVA}_{254}-\mathrm{TOCl}$ & 0.700 \\
SUVA $_{254}-\mathrm{TOBr}$ & 0.723 \\
SUVA $_{254}$ - TOI & 0.035 \\
\% aromatic C - TOX & 0.792 \\
\% aromatic C - TOCl & 0.792 \\
\% aromatic C - TOBr & 0.758 \\
\% aromatic C - TOI & 0.008 \\
\hline
\end{tabular}




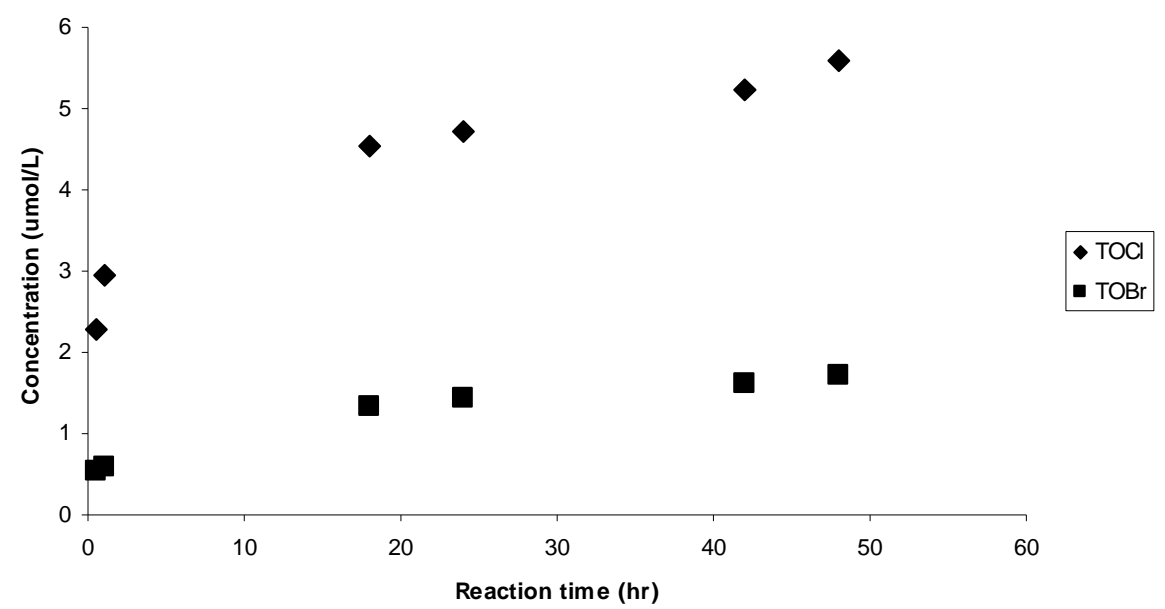

Figure 1: Formation of TOCl and TOBr in the chlorination of LR HPO $\left(2.6 \mathrm{mg} \mathrm{L}^{-1}\right.$ DOC, $10 \mathrm{mg} \mathrm{L}^{-1}$ $\mathrm{Cl}_{2}, \mathrm{pH} 7,300 \mu \mathrm{g} \mathrm{L}^{-1}$ bromide ion, $50 \mu \mathrm{g} \mathrm{L}^{-1}$ iodide ion, $20^{\circ} \mathrm{C}$ ). TOI was not detected in all samples.

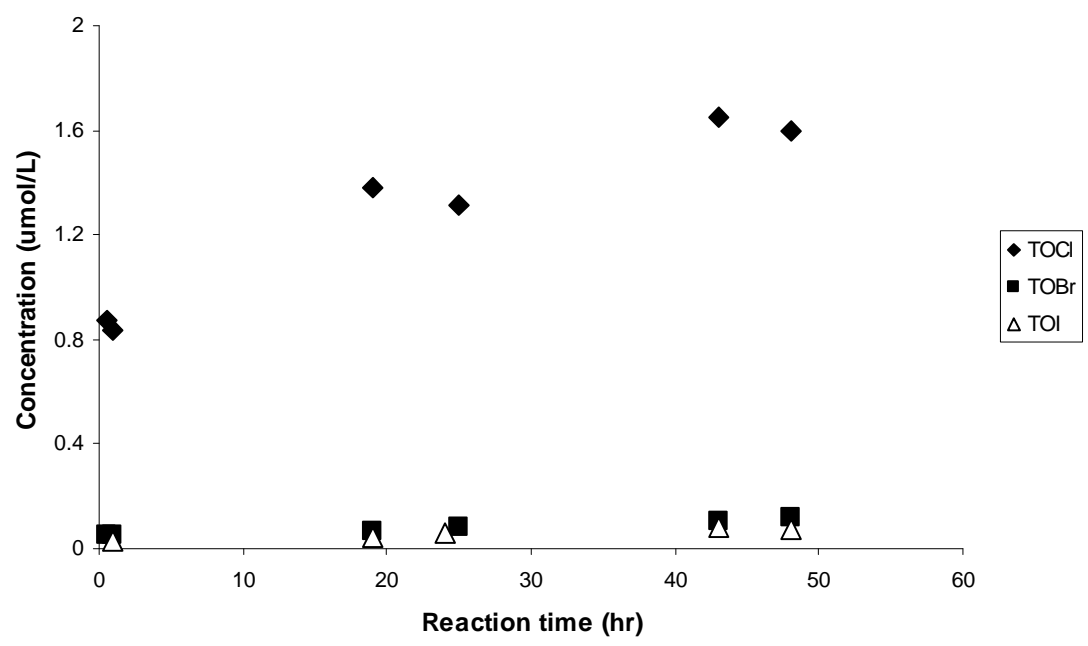

Figure 2: Formation of TOCl, TOBr and TOI in the chloramination of LR HPO (2.6 mg L ${ }^{-1}$ DOC, 10 $\mathrm{mg} \mathrm{L}^{-1} \mathrm{NH}_{2} \mathrm{Cl}, \mathrm{pH} 8,300 \mu \mathrm{g} \mathrm{L}^{-1}$ bromide ion, $50 \mu \mathrm{g} \mathrm{L}^{-1}$ iodide ion, $20^{\circ} \mathrm{C}$ ) 


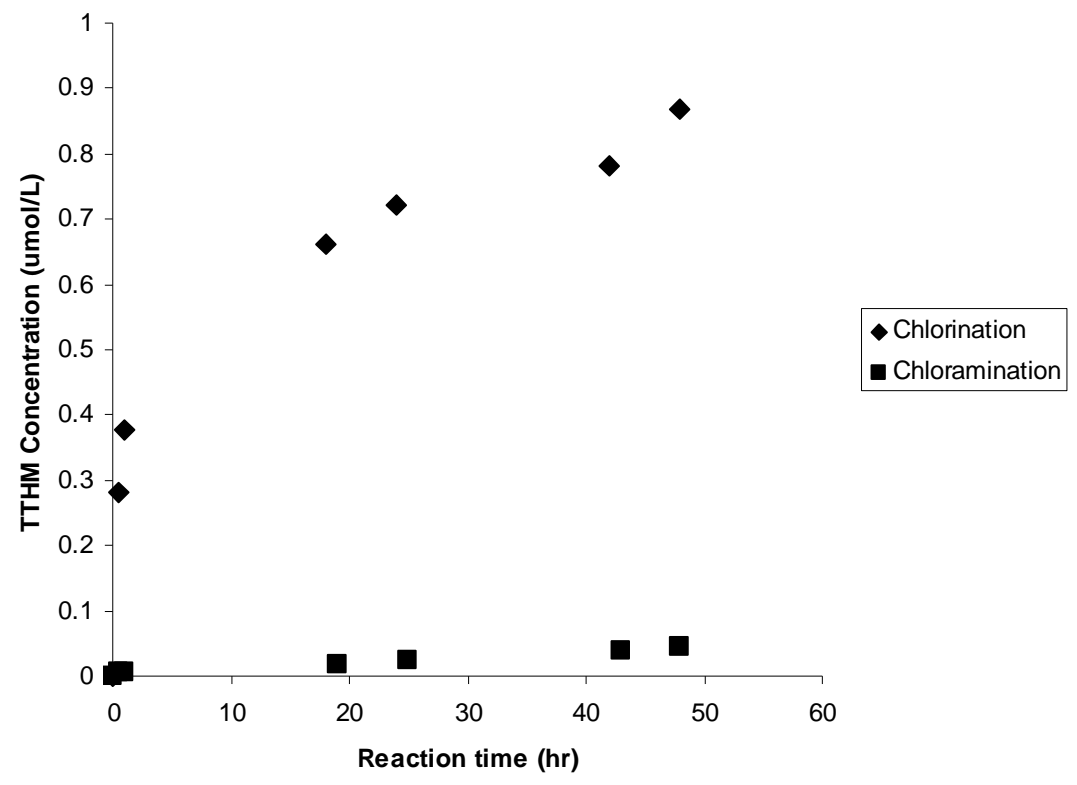

Figure 3: Formation of total THMs in the chlorination and chloramination of LR HPO $\left(2.6 \mathrm{mg} \mathrm{L}^{-1}\right.$ DOC, $300 \mu \mathrm{g} \mathrm{L}^{-1}$ bromide ion, $50 \mu \mathrm{g} \mathrm{L}^{-1}$ iodide ion, $20^{\circ} \mathrm{C}$, chlorination: $10 \mathrm{mg} \mathrm{L}^{-1} \mathrm{Cl}_{2}$ at $\mathrm{pH} 7$, chloramination: $10 \mathrm{mg} \mathrm{L}^{-1} \mathrm{NH}_{2} \mathrm{Cl}$ at $\mathrm{pH} 8$ ) 


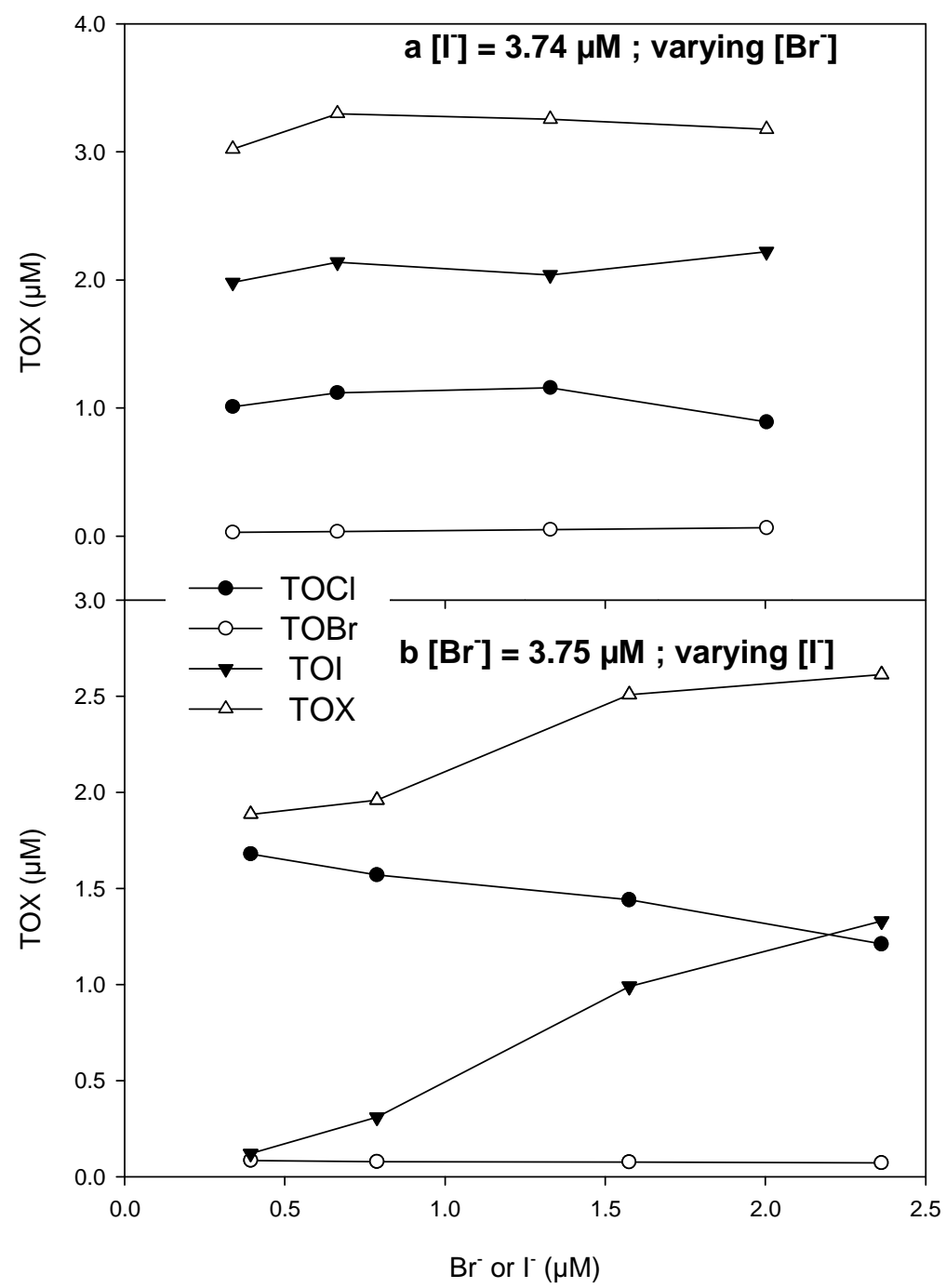

Figure 4: TOX distribution after chloramination of LR HPOA, with varying initial a) bromide ion and b) iodide ion concentration $\left(2.5 \mathrm{mg} \mathrm{L}^{-1} \mathrm{DOC}, \mathrm{NH}_{2} \mathrm{Cl}\right.$ dose $\left.10 \mathrm{mg} \mathrm{L}^{-1}, \mathrm{pH} 8,20^{\circ} \mathrm{C}\right)$ 


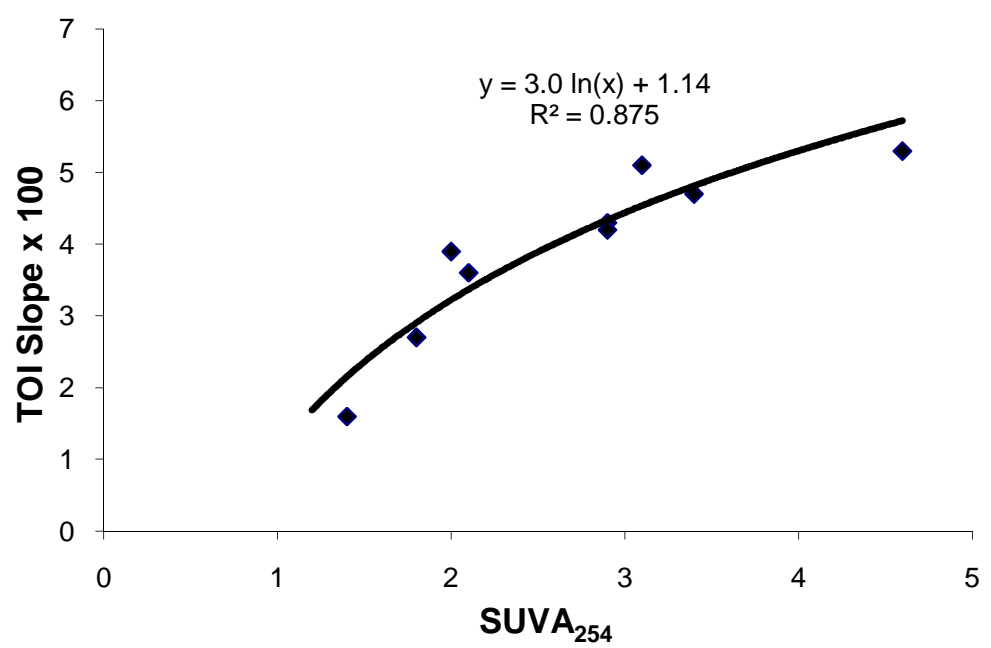

Figure 5: Logarithmic function of $\mathrm{SUVA}_{254}$ values and the slopes of the linear regressions of [TOI] and initial [I'] for all NOM isolates 